\title{
How to get there? A critical assessment of accessibility objectives and indicators in metropolitan transportation plans
}

\begin{abstract}
Accessibility, the ease of reaching destinations, is increasingly seen as a complimentary and in some cases alternative to the mobility oriented planning paradigm, as it allows capturing the complex interactions between land use and transportation systems while providing a social perspective on transportation planning. However, although accessibility has been extensively researched in the last decades, it is still largely marginalized in transportation planning practice. Accordingly, the aim of this study is to critically assess how accessibility is incorporated into metropolitan transportation plans and translated into performance indicators around the world, to ultimately derive policy recommendations. This research assesses 32 recent metropolitan transport plans from North America, Europe, Australia and Asia with respect to their goals, objectives and performance indicators. The results suggest that there is a trend toward a greater integration of accessibility objectives in transport plans, yet few plans have accessibility-based indicators that can guide their decision-making processes. Our findings show that in order to foster accessibilitybased approaches to transportation planning, plans need to have clearly defined accessibility goals with a distinction between accessibility and mobility. Furthermore, multi-criteria analysis approaches including accessibility indicators need to guide the decision-making process. This study contributes to a greater understanding of the challenges and successes associated with implementing accessibility in transport planning.
\end{abstract}

Key words: Access to destinations; Performance indicators; Sustainable transportation; Paradigm shift

FOR CITATION PLEASE USE: Boisjoly, G., \& El-Geneidy A. (2017). How to get there? A critical assessment of accessibility objectives and indicators in metropolitan transportation plans. Transport Policy, 55, 38-50. 


\section{INTRODUCTION}

Accessibility is increasingly seen as an alternative to mobility oriented planning paradigm (Geurs, Krizek, \& Reggiani, 2012), as it allows capturing the complex interactions between land use and transportation systems (Hansen, 1959) and provides a social perspective on transportation planning (Banister, 2008; Lucas, 2012). While mobility merely reflects the ease of moving, accessibility addresses the ease of reaching desired destinations, which is in fact the reason why people undertake trips (Preston \& Rajé, 2007). Accessibility is one of the most comprehensive measures to assess the complex performance of land use and transportation systems in a region. As it has been well documented in the literature, accessibility can help in reducing car use, increasing social equity, and support economic development. Accordingly, transportation planning is increasingly framed in terms of access to opportunities (Geurs et al., 2012; Handy, 2008; Lucas, 2012; Manaugh, Badami, \& El-Geneidy, 2015; Preston \& Rajé, 2007). Nevertheless, the concept of mobility is still prioritized over accessibility in practice (Halden, 2011; Levinson, 2005; Proffitt, Bartholomew, Ewing, \& Miller, 2015).

The aim of this paper is to critically assess how accessibility is incorporated into metropolitan transportation plans and translated into performance indicators around the world. This analysis seeks to identify best practices and provide guidelines on how to effectively use accessibility in planning. In order to do so, a qualitative content analysis of 32 recent plans from metropolitan areas in North America, Europe, Australia and Asia is conducted. The analysis focuses on the vision, goals, objectives and performance indicators stated in the plans. The general trends as well as the best practices are highlighted in this study. This study contributes to a greater understanding of practical challenges and successes associated with accessibility planning. This research is of relevance to decision-makers and transportation planners wishing to better integrate accessibility in their plans and practice. It also provides researchers with a greater understanding of the current planning practices, and potentially contribute to bridging the gap between ongoing research and planning practice.

\section{LITERATURE REVIEW}

\section{What is Accessibility?}

In simple words, accessibility can be understood as the ease of reaching services and activities (Litman, 2013). For the purpose of this study, we focus on geographical accessibility, that is the 
ease of reaching destinations (Preston \& Rajé, 2007). Following this definition, accessibility is largely contingent on the spatial distribution of destinations, the land use component, and the ability to move from one place to another, the transport component (Geurs \& van Wee, 2004). The land use component is related to the spatial distribution of opportunities. Urban opportunities can include, but are not limited to, jobs, health services and retail stores. The transport component refers to the transport infrastructure specific to each mode. In addition to transport and land use, there are temporal and individual components to accessibility (Geurs \& van Wee, 2004). The availability of opportunities for example (opening hours of shops and services, job starting time) represents temporal elements, whereas personal characteristics such as income and car ownership reflect the individual component.

Given the multiple components of accessibility, accessibility can be measured in different ways (Geurs \& van Wee, 2004; Handy \& Niemeier, 1997; Paez, Scott, \& Morency, 2012). Firstly, accessibility can be measured at the individual level (person-based), or at the location level (placebased) (Miller, 2005). Whereas person-based metrics focus on the individual component, placebased metrics mainly account for the land use and transport components. The individual component is sometimes included in location-based studies by stratifying population by age group or socio-economic characteristics, and by segmenting destinations (by job types for example) (Fan, Guthrie, \& Levinson, 2012; Alexandre Legrain, Buliung, \& El-Geneidy, 2015; A. Legrain, Buliung, \& El-Geneidy, 2016; Paez, Mercado, Farber, Morency, \& Roorda, 2010). Location-based accessibility is most commonly used by policy-makers as it provides a comprehensive measure of the land use and transport system at the regional level (Dodson, Gleeson, Evans, \& Sipe, 2007). Location-based metrics typically accounts for the number of opportunities that can be reached from a specific location, based on the travel costs to destinations using a specific mode (Handy \& Niemeier, 1997).

Travel costs are generally measured based on travel time or distance (Geurs \& van Wee, 2004; Handy, 1994; Hansen, 1959; A. Owen \& Levinson, 2014; Vickerman, 1974). Two locationbased measures are commonly used in accessibility research. The first one is the gravity-based measure which discounts all opportunities based on their travel costs. The second one is the cumulative-opportunity measure, which only counts the opportunities that are within a specific travel costs threshold. Gravity-based measures better reflect travel behavior as it accounts for the travelers' perceptions of time (Ben-Akiva \& Lerman, 1979). This measure is, however, more 
complex to generate, as a distance-decay function must be calculated, and more difficult to interpret and communicate, as it is not directly expressed in terms of the number of opportunities (Geurs \& van Wee, 2004; A. Owen \& Levinson, 2014). On the other hand, cumulative-opportunity measures are easy to generate and interpret. Furthermore, these measures are highly correlated with gravity-based measures (El-Geneidy \& Levinson, 2006), and hence represent an adequate measure of regional accessibility (Boisjoly \& El-Geneidy, 2016).

\section{From Mobility to Accessibility}

Transportation planning has emerged as an isolated field that focused mainly on mobility, defined as the ease of moving. In this context, mobility indicators such as travel speed and travel times were put forward, with a focus on motorized transportation (Banister, 2008). Accessibility was first introduced by Hansen in 1959 to capture the interaction between the land use and the transportation networks. Following Hansen's work, researchers started to emphasize the need to include accessibility as a performance indicator in land use and transportation plans as an alternative approach to mobility-based transportation planning (Koenig, 1980; Morris, Dumble, \& Wigan, 1979; Wachs \& Kumagai, 1973). They argued that accessibility better reflected the economic and social benefits of the network, namely in terms of land values and quality of life (Koenig, 1980; Wachs \& Kumagai, 1973). More recently, accessibility has been put forward as a key element of land use and transportation planning (Banister, 2008; Handy, 2002; Straatemeier, 2008), namely with respect to social equity, economic development and environmental impacts (Handy, 2002; Lucas, 2012; Preston \& Rajé, 2007). Whereas mobility-based approaches focus on travel time minimization, planning for accessibility aims at providing all individuals with a reasonable travel times to a variety of destinations (Banister, 2008). As a result, planning for accessibility gives greater consideration to active and public transportation, and incorporate land use policies that reduce distances between activities (Banister, 2008).

Although accessibility has been a central theme of research in the last decades and has recently gained attention in the planning sector, transportation planning is still dominated by a mobility-oriented paradigm. In a quantitative assessment of American transportation plans, Proffitt et al. (2015) found that accessibility is increasingly incorporated in plans, especially in larger metropolitan areas, but is still marginally addressed compared to mobility. Furthermore, in those plans accessibility is often not clearly defined and thus often used as a buzzword. Similarly, in an 
assessment of four metropolitan plans in California, Handy (2005) found that plans were developed around mobility. Nevertheless, the plans addressed some concerns with accessibility, although they were not defined as such. In the United Kingdom (UK) context, the concept of accessibility has been widely used, mainly due to the establishment of accessibility planning requirements by the national government (Halden, 2011). However, given the broad and flexible guidelines, accessibility is often "misused" and "abused in practice" (Halden, 2011). Furthermore, there is no consensus about which accessibility indicators and metrics should be used (Halden, 2011). While a plethora of measures have been developed in academic settings, their practical implementation remains limited, which raises questions about their usability (Boisjoly \& ElGeneidy, 2016; Curl, Nelson, \& Anable, 2011; Geurs \& van Wee, 2004). Overall, research has shown that the paradigm shift from mobility to accessibility is far from complete. Accessibility is not yet a mature concept in planning, and is accordingly not being used effectively.

Given the increase interest in accessibility planning and the challenges related to its implementation, this study critically assesses transportation plans from metropolitan areas in North America, Europe, Australia and Asia. This study expands upon existing research in the United States (US) and the UK to include a greater variety of planning contexts. Furthermore, no study has, to our knowledge, investigated a broad range of plans from a qualitative perspective to identify best practices and successful implementations of accessibility indicators.

\section{RESEARCH FRAMEWORK AND METHODOLOGY}

The ultimate goal of this study is to investigate which practices effectively incorporate accessibility into transportation planning. To achieve this research goal, this study explores the integration of accessibility into metropolitan transportation plans and seeks to answer the following research questions:

- To what extent and how is accessibility included in metropolitan transportation plans around the world?

- To what extent are accessibility goals translated into performance indicators reflecting the ease of reaching destinations?

- What are the best practices and how could accessibility objectives be better integrated in metropolitan transportation plan? 
To address our research questions, we assessed long-range metropolitan transportation plans and related documents from 32 metropolitan areas around the world. We defined three inclusion criteria for the metropolitan areas: population size, availability of documents and location. Firstly, we focused on metropolitan areas located in high-income countries, in order to get a relatively homogenous sample. Secondly, metropolitan areas with a population greater than 2.5 million inhabitants were included. A lower population threshold ( 2 million) was selected for Europe, in order to include a broader variety of metropolitan areas. Thirdly, the metropolitan area needed to have a transportation plan available in English or French. In total, 18 metropolitan areas in the U.S. were selected, 3 in Canada, 8 in Europe, 2 in Australia, and one in Asia (Singapore). The respective plans are presented in TABLE 1.

Metropolitan transportation plans, which include goals, objectives, and indicators, have been selected to assess how accessibility is considered in urban transportation planning, as done in previous studies (Handy, 2005; Proffitt et al., 2015). Handy (2005) examined four metropolitan transportation plans to assess the use of mobility and accessibility in practice. Building on this approach, Proffitt et al. (2015) quantitatively assessed the use of accessibility in 42 metropolitan plans in the US. Manaugh et al. (2015) adopted a similar approach to examine how equity objectives are included in transportation planning. Our study builds on these previous studies, and expands the analysis conducted by Handy (2005) and Proffitt et al. (2015) by assessing a broader variety of plans. Furthermore, a qualitative approach is taken to allow an in-depth understanding of the plans. Finally, metropolitan transportation plans were selected, rather than specific transit plans, in order to focus on authorities that typically deal with both land use and transportation strategies, and to include all modes of transportation. Nevertheless, in most cases, metropolitan transportation plans incorporate the main elements of local transit plans, and set orientations for future transit development.

For each metropolitan area, the most recent transportation plan was selected. Except for four plans, all of them are from 2010 or later. Due to differences in political structures, there are some discrepancies in the type of authority that developed the plan in each metropolitan area. It was typically a metropolitan planning organization, a City administration, or a transit agency.

To answer our research questions, a structuring content analysis was conducted, with the aim of extracting the relevant material from the plans (Mayring, 2014). The analysis was conducted in four phases. The first step consisted of skimming the planning document to identify 
the vision, goals, and objectives structuring the plan, if any. The second step was to carefully examine the performance indicators in each plan, with the purpose of extracting indicators reflecting accessibility or defined as such. A keyword in context analysis was then conducted, allowing to explore how the concept of accessibility was used (Hsieh \& Shannon, 2005). Keywords such as access, accessibility, link, connection, reach, and "get to" were used. This step was conducted to find goals, objectives or indicators that might not have been collected in the first step, and allowed to gain general understanding of the use of the concept of accessibility in the plan. Finally, a subset of plans was assessed more in details to evaluate accessibility analysis and accessibility indicators. These plans were selected based on the previous steps, and the aim was to find relevant and various examples of the use of accessibility indicators.

The research method used in this study allows assessing the current trends and best practices in the use of accessibility in metropolitan transportation plans. However, there are some limitations to our studies. Firstly, the study focuses on metropolitan transportation plans, typically under the responsibility of a regional or municipal planning organization. As such, distinct transit plans from local public transit authorities fall outside the scope of this study. While further research could look more specifically into local transit plans, the current study allows assessing how accessibility is considered in transportation planning at the metropolitan scale, and for all modes. Secondly, this study focuses on the general trends, but does not allow an in-depth comparison between the plans and planning contexts. Thirdly, this study evaluates the planning documents and does not provide an in-depth understanding of the planning processes underlying the development and the implementation of the plan. It also does not address how the indicators reflect individuals' perceptions or needs, as done by Curl et al. (2011). Further research could address these limitations. Nevertheless, this study provides valuable insight on the integration of accessibility in metropolitan plans and contributes to a greater understanding of the current practices. 
TABLE 1 Accessibility-Related Objectives and Indicators From Selected Metropolitan Transportation Plans

\begin{tabular}{|c|c|c|c|}
\hline $\begin{array}{l}\text { Metropolitan } \\
\text { transportation plan }\end{array}$ & $\begin{array}{l}\text { Accessibility-related vision, goals and } \\
\text { objectives }\end{array}$ & Indicators & Comments \\
\hline \multirow[t]{2}{*}{$\begin{array}{l}\text { Transport } 2025 \text { - London, UK } \\
\text { (Transport for London, } \\
\text { 2006) }\end{array}$} & $\begin{array}{l}\text { Social goal: To improve London's accessibility (p.10) } \\
\text { Objectives: Economic development: Improvement in } \\
\text { employment accessibility, Social inclusion: Improved } \\
\text { access to employment from deprived areas (p.25) }\end{array}$ & $\begin{array}{l}\text { - The change in the number of jobs accessible by public } \\
\text { transport within } 45 \text { minutes travel time - indicators }+ \text { maps } \\
\text { - Percentage of population in the } 10 \text { percent most deprived } \\
\text { areas of London within } 45 \text { minutes travel time of } \\
\text { international and metropolitan centers } \\
\text { (p.25) }\end{array}$ & $\begin{array}{l}\text { Accessibility metrics are used as performance } \\
\text { indicators to evaluate the effectiveness of various } \\
\text { scenarios. No weight is given to the different } \\
\text { criteria, and the accessibility metrics are not present } \\
\text { in the final scenario assessment table (p.130-131). } \\
\text { Some results are stated in the plan (e.g.: An increase } \\
\text { of almost } 25 \% \text { in employment accessibility) }\end{array}$ \\
\hline & & • Bus accessibility index - maps (p.94-95) & $\begin{array}{l}\text { Bus accessibility index is used to present a regional } \\
\text { evaluation of the bus service. }\end{array}$ \\
\hline $\begin{array}{l}\text { Plan de déplacements urbains } \\
\text { Île-de-France - Paris, France } \\
\text { (Conseil régional d'île-de- } \\
\text { France, 2014) }\end{array}$ & $\begin{array}{l}\text { Objectives: Ensure access to mobility for all, Ensure } \\
\text { spatial equity in access to mobility, Improve access to } \\
\text { jobs and economic centres. (p. } 53 \text { )* }\end{array}$ & $\begin{array}{l}\cdot \text { Number of jobs accessible within } 60 \text { minutes of public } \\
\text { transport - map (p.36)* }\end{array}$ & $\begin{array}{l}\text { Accessibility maps are presented but they are not } \\
\text { discussed in the plan. }\end{array}$ \\
\hline $\begin{array}{l}\text { Urban Transportation } \\
\text { Development Plan } 2025- \\
\text { Berlin, Germany } \\
\text { (Senate Department for } \\
\text { Urban Development and the } \\
\text { Environment of the State of } \\
\text { Berlin, 2014) }\end{array}$ & $\begin{array}{l}\text { Goals: Improve accessibility in all outer city areas. } \\
\text { (p.12) } \\
\text { Objectives: Further improving links between Berlin } \\
\text { and the housing areas along the axes radiating from the } \\
\text { city. Strengthening the polycentric city structure } \\
\text { through improved accessibility to urban neighborhoods } \\
\text { and between districts and the main downtown centers. } \\
\text { (p.5) }\end{array}$ & Accessibility to both the main centers and district centers & $\begin{array}{l}\text { This indicator was included in a scenario assessment } \\
\text { (not available in English) }\end{array}$ \\
\hline $\begin{array}{l}\text { Plan de mobilité régionale - } \\
\text { Brussels, Belgium (Iris II) } \\
\text { (Bruxelles Mobilité, 2011) }\end{array}$ & $\begin{array}{l}\text { Goal: Improve regional accessibility with the most } \\
\text { appropriate modes, to support economic and social } \\
\text { dynamism (p.4)* }\end{array}$ & None & $\begin{array}{l}\text { The plan states that an accessibility map should be } \\
\text { generated in the near future, but no such map was } \\
\text { found. }\end{array}$ \\
\hline $\begin{array}{l}\text { Local Transport Plan } 3 \text { - } \\
\text { Manchester, UK } \\
\text { (Greater Manchester } \\
\text { Combined Authority, 2011) }\end{array}$ & $\begin{array}{l}\text { Objectives: To support economic growth across the } \\
\text { subregion and improve access to jobs for all. } \\
\text { (Integrated Assessments Report p.19) }\end{array}$ & $\begin{array}{l}\text { Will the LTP improve access to jobs, particularly for } \\
\text { people who suffer income or employment deprivation? } \\
\text { Will the LTP reduce journey times and improve } \\
\text { accessibility for local } \\
\text { businesses? } \\
\text { Will the LTP improve or reduce accessibility to health care } \\
\text { facilities, particularly for those who need the most health } \\
\text { services e.g. the elderly, people with disabilities and those } \\
\text { without a car? } \\
\text { Will the LTP encourage healthier lifestyles by promoting } \\
\text { the use of } \\
\text { walking, cycling and public transport and increase } \\
\text { accessibility to open greenspace and sports facilities } \\
\text { particularly for the most deprived communities and } \\
\text { sections of the community whose access needs are often } \\
\text { not catered for? } \\
\text { Will the LTP help improve accessibility through integrated } \\
\text { spatial planning? } \\
\text { (Integrated Assessments Report p.16-19) }\end{array}$ & $\begin{array}{l}\text { Questions addressing accessibility were included in } \\
\text { the integrated assessments report of the Local } \\
\text { Transport Plan } 3 \text {. }\end{array}$ \\
\hline $\begin{array}{l}\text { Plan de déplacements urbains } \\
\text { 2010-2020 - Lille, France }\end{array}$ & None & None & \\
\hline
\end{tabular}




\begin{tabular}{|c|c|c|c|}
\hline $\begin{array}{l}\text { Metropolitan } \\
\text { transportation plan }\end{array}$ & $\begin{array}{l}\text { Accessibility-related vision, goals and } \\
\text { objectives }\end{array}$ & Indicators & Comments \\
\hline \multicolumn{4}{|l|}{$\begin{array}{l}\text { (Lille Métropole } \\
\text { Communauté Urbaine, 2011) }\end{array}$} \\
\hline $\begin{array}{l}\text { Local Transport Plan } 3- \\
\text { Birmingham, UK } \\
\text { (West Midlands CEPOG, } \\
\text { 2010) }\end{array}$ & $\begin{array}{l}\text { Goals: To enhance equality of opportunity and social } \\
\text { inclusion by improving access for all to services and } \\
\text { other desired destinations within and adjacent to the } \\
\text { West Midlands Metropolitan Area. }\end{array}$ & None & $\begin{array}{l}\text { An accessibility analysis was conducted in } 2006 \text {, } \\
\text { prior to the elaboration of this plan. Accessibility is } \\
\text { very present throughout the document, but not } \\
\text { quantified in this plan. }\end{array}$ \\
\hline $\begin{array}{l}\text { Urban Mobility Strategy - } \\
\text { Stockholm, Sweden } \\
\text { (Stockholm, 2010) }\end{array}$ & $\begin{array}{l}\text { Objectives: Accessibility in the road and street } \\
\text { network is to be enhanced by increasing speeds for } \\
\text { high-capacity transportation means and raising travel- } \\
\text { time reliability for all road users }\end{array}$ & None & $\begin{array}{l}\text { The plan focuses on accessibility and proximity but } \\
\text { no quantified metrics are available. }\end{array}$ \\
\hline $\begin{array}{l}\text { Land Transport Master Plan - } \\
\text { Singapore } \\
\text { (Singapore Land Transport } \\
\text { Authority (LTA), 2013) }\end{array}$ & $\begin{array}{l}\text { Vision: We see a future where we all can get to more } \\
\text { places faster and in greater comfort as we enhance our } \\
\text { rail, bus, cycling and sheltered walkway networks, take } \\
\text { steps to improve the quality of our public transport } \\
\text { services and support new options such as car sharing. } \\
\text { (p.51) }\end{array}$ & $\begin{array}{l}\text { Vision: } 8 / 10 \text { households living within a } 10 \text {-minute walk } \\
\text { from a train station }\end{array}$ & $\begin{array}{l}\text { Access to public transport indicator is used to set the } \\
\text { vision. }\end{array}$ \\
\hline $\begin{array}{l}\text { Transport Strategy } 2012 \text { - } \\
\text { Planning for growth - } \\
\text { Melbourne, Australia } \\
\text { (City of Melbourne, 2012) }\end{array}$ & $\begin{array}{l}\text { Objectives: Making our public transport system more } \\
\text { effective: Accessibility (p.64) }\end{array}$ & $\begin{array}{l}\text { Accessibility provided by the public transport network. } \\
\text { (p.85) }\end{array}$ & $\begin{array}{l}\text { The plan indicates that an extensive accessibility by } \\
\text { public transport assessment was conducted. This is } \\
\text { reflected in the justification of the measures } \\
\text { (increased tram running speed and increased service } \\
\text { frequency). The accessibility indicator is however not } \\
\text { detailed in the plan itself. }\end{array}$ \\
\hline $\begin{array}{l}\text { Sydney Long Term Transport } \\
\text { Master Plan - Sydney, } \\
\text { Australia } \\
\text { (NSW Government, 2012) }\end{array}$ & $\begin{array}{l}\text { Goals: Support economic growth and productivity - } \\
\text { by [...] improving accessibility of people to other } \\
\text { people, opportunities, goods and services. } \\
\text { Support regional development - by improving } \\
\text { accessibility to jobs, services and people, [...]. } \\
\text { Reduce social disadvantage - by improving access to } \\
\text { goods, services and employment and education } \\
\text { opportunities for people across all parts of the State. } \\
\text { (p.22) } \\
\text { Objectives: Jobs and services need to be more } \\
\text { accessible (p.120) }\end{array}$ & $\begin{array}{l}\text { Proportion of metropolitan jobs accessible within } 30 \\
\text { minutes by public transport and private vehicle - map } \\
\text { (p.120) }\end{array}$ & $\begin{array}{l}\text { A regional evaluation is conducted to identify the } \\
\text { gaps in accessibility to jobs. }\end{array}$ \\
\hline $\begin{array}{l}\text { Vancouver Transportation } \\
\text { Investment - Vancouver, } \\
\text { Canada (Mayor's Council on } \\
\text { Regional Transportation, } \\
\text { 2014) }\end{array}$ & None & Access to potential workers, jobs, and markets. (p.28) & $\begin{array}{l}\text { The plan states that the projects were assessed based } \\
\text { on these accessibility indicators. }\end{array}$ \\
\hline $\begin{array}{l}\text { Transportation Plan - } \\
\text { Montreal, Canada } \\
\text { (Ville de Montréal, 2008) }\end{array}$ & None & None & $\begin{array}{l}\text { Improving accessibility to employment clusters is } \\
\text { discussed in the text as a benefit of various } \\
\text { transportation projects, but only in general terms. } \\
\text { There is no objective or indicators related to } \\
\text { accessibility. }\end{array}$ \\
\hline $\begin{array}{l}\text { The Big Move - Toronto, } \\
\text { Canada } \\
\text { (Metrolinx, 2008) }\end{array}$ & $\begin{array}{l}\text { Objectives: Increased transportation options for } \\
\text { accessing a range of destinations, Improved } \\
\text { accessibility for seniors, children and individuals with } \\
\text { special needs and at all income levels. (p.15) }\end{array}$ & $\begin{array}{l}\text { - Percent of people who live within two km of rapid transit, } \\
\text { from } 42 \% \text { to } 81 \% \text {. (p. } 58 \text { ) }\end{array}$ & $\begin{array}{l}\text { An access to public transport indicator shows the } \\
\text { results of the modelling forecast, and is used to } \\
\text { highlight the benefits provided by The Big Move. }\end{array}$ \\
\hline
\end{tabular}




\begin{tabular}{|c|c|c|c|}
\hline $\begin{array}{l}\text { Metropolitan } \\
\text { transportation plan }\end{array}$ & $\begin{array}{l}\text { Accessibility-related vision, goals and } \\
\text { objectives }\end{array}$ & Indicators & Comments \\
\hline $\begin{array}{l}\text { The Atlanta Region's Plan - } \\
\text { Atlanta, US } \\
\text { (Atlanta Regional } \\
\text { Commission, 2016) }\end{array}$ & None & $\begin{array}{l}\text { - Number of low-wage jobs within } 60 \text { minutes by transit } \\
\text { from equitable target areas. } \\
\text { - Transit ( } 60 \text { minutes) and walking ( } 0.5 \text { miles) travel sheds } \\
\text { from i) libraries, ii) school, ii) grocery stores, iii) major } \\
\text { hospitals, and iv) public parks, located in equitable target } \\
\text { areas. } \\
\text { - Areas within } 0.5 \text { miles of a transit station } \\
\text { (Appendix J) }\end{array}$ & $\begin{array}{l}\text { Accessibility metrics are used to conduct an EJ** } \\
\text { assessment. It provides diagnosis of accessibility to } \\
\text { various destinations for deprived areas. }\end{array}$ \\
\hline $\begin{array}{l}\text { Maximize } 2040 \text { - Baltimore, } \\
\text { US } \\
\text { (Baltimore Regional } \\
\text { Transportation Board, 2016) }\end{array}$ & $\begin{array}{l}\text { Goals: Improve Accessibility: Help people of all ages } \\
\text { and abilities to access specific destinations. (p.S-2) }\end{array}$ & $\begin{array}{l}\text { None } \\
\text { - Access to Job/Activity Centers (Highway): Degree to } \\
\text { which project improves infrastructure enabling access to } \\
\text { and supporting major Job/Activity Centers ( } 1 / 2 \text { mile buffer } \\
\text { analysis - per mile benefits) } \\
\text { - Transit station/stops: Degree to which project supports } \\
\text { access to specific destinations (EJ population - } 1 / 4 \text { mile } \\
\text { buffer analysis } \\
\text { - Access to Job/Activity Centers (Transit): Degree to which } \\
\text { project improves infrastructure enabling access to and } \\
\text { supporting major Job/Activity Centers (1/4 mile buffer } \\
\text { analysis - per mile benefits) } \\
\text { (p.F-2) }\end{array}$ & $\begin{array}{l}\text { With respect to the accessibility goal, no accessibility } \\
\text { indicators are used. Rather, it is mobility indicators. } \\
\text { Accessibility indicators are used in a multi-criteria } \\
\text { assessment of projects submitted to Maximize } 2040 \\
\text { by local jurisdictions. A score is given based on } \\
\text { specified criteria. }\end{array}$ \\
\hline $\begin{array}{l}\text { Long Range Transportation } \\
\text { Plan } 2040 \text { - Boston, US } \\
\text { (Boston Region Metropolitan } \\
\text { Planning Organization, } \\
\text { 2015) }\end{array}$ & $\begin{array}{l}\text { Vision: A modern transportation system that is safe, } \\
\text { uses new technologies, and provides equitable access, } \\
\text { excellent mobility, and varied transportation options... } \\
\text { (p.ES1) } \\
\text { Objectives: Increase percentage of population and } \\
\text { places of employment within one-quarter mile of transit } \\
\text { stations and stops. Increase percentage of population } \\
\text { and places of employment with access to bicycle } \\
\text { facilities (p.ES3) }\end{array}$ & $\begin{array}{l}\text { None } \\
\text { - Number of industrial, retail, and service jobs within a } 40 \text { - } \\
\text { minute transit trip and a } 20 \text {-minute auto trip } \\
\text { • Number of hospitals, weighted by number of beds, within } \\
\text { a } 40 \text {-minute transit trip and a } 20 \text {-minute auto trip } \\
\text { - Number of two- and four-year institutions of higher } \\
\text { education, weighted by enrollment, within a } 40 \text {-minute } \\
\text { transit trip and a } 20 \text {-minute auto trip }\end{array}$ & $\begin{array}{l}\text { Clear accessibility objectives are stated, but they are } \\
\text { not discussed in the plan. } \\
\text { An EJ assessment is conducted and analyzes the } \\
\text { different in accessibility from equity and non-equity } \\
\text { zones. }\end{array}$ \\
\hline $\begin{array}{l}\text { Connections } 2040- \\
\text { Philadelphia, US } \\
\text { (Delaware Valley Regional } \\
\text { Planning Commission, 2013) }\end{array}$ & $\begin{array}{l}\text { Goals: Increase accessibility and mobility (p.4) } \\
\text { Objectives: Provide access to key employment, } \\
\text { commercial, institutional, and tourism centers in the } \\
\text { region (p.78) }\end{array}$ & None & $\begin{array}{l}\text { There are no accessibility indicators although there } \\
\text { are clear accessibility objectives and goals. }\end{array}$ \\
\hline $\begin{array}{l}\text { Bridging Our Communities - } \\
\text { Houston, US (Houston- } \\
\text { Galveston Area Council, } \\
\text { 2016) }\end{array}$ & $\begin{array}{l}\text { Vision: In the year 2040, our region will have a } \\
\text { multimodal transportation system through coordinated } \\
\text { investments that supports a desirable quality of life, } \\
\text { enhanced economic vitality and increased safety, access } \\
\text { and mobility. (p.5) }\end{array}$ & None & $\begin{array}{l}\text { There are no accessibility objectives among the set of } \\
\text { objectives or goals. }\end{array}$ \\
\hline $\begin{array}{l}\text { Regional Transportation Plan - } \\
\text { Phoenix, US } \\
\text { (Maricopa Association of } \\
\text { Governments, 2006) }\end{array}$ & $\begin{array}{l}\text { Vision: To enable people in Maricopa County to travel } \\
\text { with ease using safe, accessible, efficient, dependable } \\
\text { and integrated public transportation services. (p.3) }\end{array}$ & None & $\begin{array}{l}\text { There are no accessibility objectives among the set of } \\
\text { objectives or goals. }\end{array}$ \\
\hline
\end{tabular}




\begin{tabular}{|c|c|c|c|}
\hline $\begin{array}{l}\text { Metropolitan } \\
\text { transportation plan }\end{array}$ & $\begin{array}{l}\text { Accessibility-related vision, goals and } \\
\text { objectives }\end{array}$ & Indicators & Comments \\
\hline $\begin{array}{l}2040 \text { Transportation Policy } \\
\text { Plan - St-Paul, US } \\
\text { (Metropolitan Council - St- } \\
\text { Paul, 2015) }\end{array}$ & $\begin{array}{l}\text { Goals: } \text { Access to Destinations: People and businesses } \\
\text { prosper by using a reliable, affordable, and efficient } \\
\text { multimodal transportation system that connects them to } \\
\text { destinations throughout the region and beyond. (p.62) }\end{array}$ & $\begin{array}{l}\text { None } \\
\text { Access to jobs and activities (p.6-55) } \\
\text { - Increase in job accessibility on the transit system within } \\
45 \text { min. } \\
\text { - Number of regional job concentrations served } \\
\text { - Number of jobs reachable within } 30 \text { min. by car/public } \\
\text { transport (p.10-13) }\end{array}$ & $\begin{array}{l}\text { Performance measures related to Access to } \\
\text { Destinations goal do not reflect accessibility. } \\
\text { Possible accessibility-based measures are defined for } \\
\text { setting regional transitway priorities. } \\
\text { A comparative accessibility analysis is conducted for } \\
\text { people of color, the general population and people } \\
\text { with low incomes, as part of the EJ assessment }\end{array}$ \\
\hline $\begin{array}{l}\text { Bay Area Plan - San } \\
\text { Francisco, US (Metropolitan } \\
\text { Transportation Commission, } \\
\text { 2013) }\end{array}$ & None & None & $\begin{array}{l}\text { Two accessibility performance measures are defined. } \\
\text { However, the related indicators do not reflect } \\
\text { accessibility. }\end{array}$ \\
\hline $\begin{array}{l}\text { Washington Transportation } \\
\text { Plan } 2035 \text { - Washington, D.C., } \\
\text { US } \\
\text { (National Capital Region } \\
\text { Transportation Planning } \\
\text { Board, 2015) }\end{array}$ & None & None & \\
\hline $\begin{array}{l}\text { Plan } 2040 \text { - New York City, } \\
\text { US } \\
\text { (New York Metropolitan } \\
\text { Transportation Council, } \\
\text { 2013) }\end{array}$ & None & None & $\begin{array}{l}\text { The plan states that the New York metropolitan } \\
\text { transit authority is conducting an equity analysis } \\
\text { based on public transport access. This analysis is } \\
\text { however not readily available. }\end{array}$ \\
\hline $\begin{array}{l}\text { Mobility } 2040 \text { - Dallas, US } \\
\text { (North Central Texas } \\
\text { Council of Governments, } \\
\text { 2016) }\end{array}$ & $\begin{array}{l}\text { Goals: Ensure all communities are provided access to } \\
\text { the regional transportation system and planning } \\
\text { process. (p.14) }\end{array}$ & $\begin{array}{l}\text { - Population within } 15 \text { minutes to hospitals } \\
\text { - Number of jobs accessible within } 30,60 \text { and } 90 \text { minutes } \\
\text { by auto/transit and within biking/walking distance ( } 2 \\
\text { miles) } \\
\text { (p.B-28) }\end{array}$ & $\begin{array}{l}\text { A detailed EJ assessment is presented. The } \\
\text { accessibility indicators are generated for various } \\
\text { socio-economic groups. }\end{array}$ \\
\hline $\begin{array}{l}\text { Plan } 2040 \text { - Newark, US } \\
\text { (North Jersey } \\
\text { Transportation Planning } \\
\text { Authority, 2013) }\end{array}$ & None & None & $\begin{array}{l}\text { There is no accessibility objectives among the set of } \\
\text { objectives or goals }\end{array}$ \\
\hline $\begin{array}{l}\text { Transportation } 2040 \text { Plan } \\
\text { Update } 2014 \text { - Seattle, US } \\
\text { (Puget Sound Regional } \\
\text { Council, 2014) }\end{array}$ & None & $\begin{array}{l}\cdot \text { How well does the project improve access to areas of } \\
\text { opportunity? } \\
\text { - How well does the project support job retention or } \\
\text { expansion by improving access? } \\
\text { - How well does the project provide access to job-related } \\
\text { training or educational opportunities? } \\
\text { (p.D-19 in Appendix P) }\end{array}$ & $\begin{array}{l}\text { Accessibility indicators are used in a multi-criteria } \\
\text { prioritization framework. Scores from } 1 \text { to } 4 \text { are } \\
\text { given for each indicator based on specific conditions. }\end{array}$ \\
\hline $\begin{array}{l}2050 \text { Regional Transportation } \\
\text { Plan - San Diego, US (San } \\
\text { Diego Association of } \\
\text { Governments, 2011) }\end{array}$ & $\begin{array}{l}\text { Goals: Better link jobs, homes, and major activity } \\
\text { centers by enabling more people to use transit and to } \\
\text { walk and bike. (p.1-3) } \\
\text { Social equity goal: Ensure access to jobs, services, and } \\
\text { recreation for populations with fewer transportation } \\
\text { choices. (p.4-4) }\end{array}$ & $\begin{array}{l}\text { - Access to transit: percentage of homes within half a mile } \\
\text { of a transit stop, including Trolley and light rail stations, } \\
\text { bus stops, etc. } \\
\text { - Access to Amenities (auto and transit): Percentage of } \\
\text { Population within: } 30 \text { minutes of education institutions/of } \\
\text { the airport and } 15 \text { minutes of healthcare/of parks or } \\
\text { beaches (p.4-16) }\end{array}$ & $\begin{array}{l}\text { A social equity analysis was conducted for all } \\
\text { scenarios to make sure they were consistent with EJ } \\
\text { assessment. A broad variety of destinations is } \\
\text { included. }\end{array}$ \\
\hline
\end{tabular}




\begin{tabular}{|c|c|c|c|}
\hline $\begin{array}{l}\text { Metropolitan } \\
\text { transportation plan }\end{array}$ & $\begin{array}{l}\text { Accessibility-related vision, goals and } \\
\text { objectives }\end{array}$ & Indicators & Comments \\
\hline \multirow[t]{3}{*}{$\begin{array}{l}\text { Regional Transportation Plan } \\
2040 \text { - Detroit, US (Southeast } \\
\text { Michigan Council of } \\
\text { Governments, 2013) }\end{array}$} & $\begin{array}{l}\text { Vision: [The plan should contribute to] access to } \\
\text { services, jobs, markets, and amenities (p.3) } \\
\text { Objective: Increasing the percentage of households } \\
\text { with access to jobs, services and recreational } \\
\text { opportunities. (p.46) }\end{array}$ & $\begin{array}{l}\text {-Percent of households with access to jobs/to amenities/to } \\
\text { services (p.4) }\end{array}$ & $\begin{array}{l}\text { Specific performance indicators are defined to } \\
\text { measure progress towards achieving desired } \\
\text { outcomes. A broad variety of destinations is } \\
\text { included. Yet, the current plan does not include these } \\
\text { performance indicators. }\end{array}$ \\
\hline & & $\begin{array}{l}\text { - Percent of the region's population/elderly } \\
\text { population/low-income households/jobs is within } 1 / 4 \\
\text { mile/1/2 mile of an existing bus route. (p.65) }\end{array}$ & $\begin{array}{l}\text { Indicators of access to transport are included in the } \\
\text { plan to describe the public transport service coverage. }\end{array}$ \\
\hline & & $\begin{array}{l}\text { - Average number of job/shopping opportunities from } \\
\text { traffic analysis zone ( } 25 \text { minutes by transit, } 50 \text { minutes by } \\
\text { car) } \\
\text { - Percent of population close to a hospital/a college/a major } \\
\text { retail center ( } 25 \text { minutes by transit, } 50 \text { minutes by car) } \\
\text { (EJ: p. } 10-11 \text { ) }\end{array}$ & $\begin{array}{l}\text { A detailed accessibility analysis is conducted to } \\
\text { assess the differentiated impacts on various } \\
\text { demographic groups in the region (p.27). }\end{array}$ \\
\hline $\begin{array}{l}\text { Regional Transportation Plan } \\
2040 \text { - Los Angeles, US } \\
\text { (Southern California }\end{array}$ & $\begin{array}{l}\text { Goals: Maximize mobility and accessibility for all } \\
\text { people and goods in the region. (p.64) }\end{array}$ & None & $\begin{array}{l}\text { There is no accessibility indicators related to the } \\
\text { main accessibility goal. }\end{array}$ \\
\hline $\begin{array}{l}\text { Association of Governments, } \\
\text { 2016) }\end{array}$ & & $\begin{array}{l}\text { - Share of employment and shopping destinations within a } \\
\text { one- and two-mile travel buffer from each neighborhood; } \\
\text { within } 30 \text { minutes by auto or } 45 \text { minutes by bus or all } \\
\text { transit modes during the evening peak period. } \\
\text { - Share of population within a one- and two-mile travel } \\
\text { buffer from a regional park or school; also, share of park } \\
\text { acreage that can be reached within } 30 \text { minutes by auto or } \\
45 \text { minutes by bus or all transit modes during the evening } \\
\text { peak period. (p.167) }\end{array}$ & $\begin{array}{l}\text { Accessibility indicators are used to conduct the EJ } \\
\text { assessment. }\end{array}$ \\
\hline $\begin{array}{l}\text { The Southwestern PA plan - } \\
\text { Pittsburgh, US (Southwestern } \\
\text { Pennsylvania Commission, } \\
\text { 2014) }\end{array}$ & None & $\begin{array}{l}- \text { Proximity to transit: Housing units within } 0.5 \text { miles of a } \\
\text { transit stop } \\
\text { - Proximity to parks and trails: Proximity to parks and } \\
\text { trails ( } 0.5 \text { miles) (p.5-7) }\end{array}$ & $\begin{array}{l}\text { These indicators are identified as relevant } \\
\text { performance measures for land use and transportation } \\
\text { projects, but are not included in the current plan. }\end{array}$ \\
\hline $\begin{array}{l}\text { Go To } 2040 \text { Update - } \\
\text { Chicago, US } \\
\text { (The Chicago Metropolitan } \\
\text { Agency for Planning, 2014) }\end{array}$ & None & $\begin{array}{l}\text { - Percentage of jobs and population within at least } \\
\text { moderate access to transit, based on: (1) weekly frequency } \\
\text { of transit service, (2) activities that can be reached via a } \\
\text { single direct transit route, (3) proximity to a transit stop or } \\
\text { station measured over the network, and (4) the pedestrian } \\
\text { friendliness of the surrounding area. (p.19) }\end{array}$ & $\begin{array}{l}\text { An interesting composite index of access to transit is } \\
\text { included in the plan. There is however no indicators } \\
\text { of access to destinations. }\end{array}$ \\
\hline
\end{tabular}

* These quotes were translated from French to English by the authors

** EJ stands for environmental justice assessment 


\section{RESULTS}

The first section of the results presents a critical assessment of the integration of accessibility into plans, whereas the second section presents an in-depth assessment of plans using accessibility indicators, and discusses the best practices.

\section{Toward a Greater Integration of Accessibility in Transportation Planning}

The results of the content analysis are presented in TABLE 1, and include the accessibility-related vision, goals, objectives and indicators. In this study, the term indicators refer to quantitative or qualitative performance measures, whereas metrics is strictly used for quantitative measures.

The keyword in context analysis revealed that almost all plans do mention the concept of accessibility in one way or another. Where earlier transportation planning approaches focused merely on mobility (Banister, 2008), most plans include accessibility in their vision, goals or objectives (see TABLE 1). For example, plans state general goals such as: improving access for all; improving access to people, jobs and services; enhancing accessibility in the road and street network; developing more connections; and helping people get to more places.

In terms of objectives, many plans do include specific accessibility objectives (see TABLE 1). These are generally framed as a way to achieve broader economic and social goals such as economic development, social inclusion and equity. The most common accessibility-based objective is to increase access to jobs, both as a way to foster economic development and to reduce social inequities. For example, Transport for London identified two access to jobs indicators, one to support economic development (through improved employment accessibility) and one to improve social inclusion (through increased access to employment for deprived areas). With respect to social inclusion or social equity, a broader range of destinations is generally included (libraries, health care facilities, greeneries, supermarkets, etc.) such as done by the Greater Manchester area. Overall most plans including accessibility objectives focus on economic development and social inclusion, mostly through access to jobs. Access to the transportation system (see Houston-Galveston Area Table 1) or to mobility (see Ile-de-France Table 1) are also often stated as goals or objectives. However, these goals do not directly address access to destinations. 


\section{Accessibility as a Buzzword}

As we have seen in the previous section, almost all of the plans do mention accessibility in one way or another. In many plans, however, accessibility or access is used in a way that does not reflect the ease of reaching various destinations and does not translate into accessibility indicators.

Whereas many plans have "access for all" goals, such framing of the accessibility goals typically reflects the principles of universal accessibility. This is not to say that universal accessibility is not a meaningful goal, but rather to illustrate the importance of clearly defining what is meant by accessibility, to ensure that access to destinations is not limited the principles of universal accessibility, but also encompasses the design of the transportation and land use system.

Furthermore, the term accessibility (or access) is often not defined, and is used as a vague term that does not translate into clear accessibility objectives. The 2040 vision of the HoustonGalveston Area Council illustrates this vague use of the term access: "In the year 2040, our region will have a multimodal transportation system through coordinated investments that supports a desirable quality of life, enhanced economic vitality and increased safety, access and mobility."(p.5). Similarly, the Southern California Council of Governments (Los Angeles) uses accessibility as a vague goal: "Maximize mobility and accessibility for all people and goods in the region."(p.64). This accessibility goal is also emphasized in the title of the plan: A Plan for Mobility, Accessibility, Sustainability and a High Quality of Life. Yet, in both the Houston plan and the Southern California Council of Governments (Los Angeles) plan, access to destinations is not addressed, although it is stated as a major goal. Accessibility is rather used as a buzzword, together with mobility, and does not refer to a distinct concept.

In fact, accessibility and mobility are often used interchangeably in plans, and most of the time when the two concepts are used interchangeably, the focus lies on mobility. Furthermore, access to mobility, rather than to destinations, is often emphasized in transportation plans, as done in the Plan de déplacements urbains Île-de-France with the goal of ensuring access to mobility. This is often reflected in the choice of accessibility indicators related to access to public transport, rather than destinations. In sum, although accessibility is mentioned in many plans, it does not imply that the ease of accessing destinations is actually addressed.

Even when specific accessibility objectives are stated in the plans, they are often translated into indicators that do not reflect accessibility. As we can see in TABLE 2, travel time is used as an indicator of accessibility in the Metropolitan Transportation Commission (San Francisco and 
Bay Area) plan, the South California Association Council of Governments (Los Angeles) plan and the San Diego Association of Governments plan. Although travel time is a component of accessibility, it does not fully reflect access to destinations. It is an indicator of mobility and does not capture the potential of interaction for opportunities, as defined by Hansen (1959). Having shorter travel times does not necessarily equate to having access to a larger number of destinations. Furthermore, as discussed by Litman (2013), strategies aiming at increasing traffic speed may in some cases lead to an overall reduction in accessibility. In sum, increased mobility does not always result in increased accessibility (Halden, 2011; Levine, Grengs, Shen, \& Shen, 2012). Interestingly, travel time is also defined as a main "accessibility" indicator at the national level in the UK (Halden, 2011).

In addition to travel times, the presence of transportation infrastructures (length of bus lanes, roads or bicycle lanes, and proportion of roads with sidewalk) are sometimes used as indicators of accessibility, such as done by the Metropolitan Council - St-Paul and the Baltimore Regional Transportation Board. Mode share is also included as an indicator of accessibility in these plans. Overall, although these indicators are relevant in measuring the quality of a transportation network, they do not necessarily indicate the achievement of an accessibility objective in the sense of the ease of reaching destinations. Whereas the presence of infrastructures and access to transit typically lead to greater accessibility, the land-use dimension of accessibility is not accounted for. Hence, providing access to a transit route that leads to the central business district does not result in the same improvement in accessibility than providing access to a transit route leading to a lowdensity suburb. Furthermore, although lower travel time and mode choice are generally associated with greater accessibility, factors other than accessibility can influence these indicators, namely car access, income and fuel prices.

TABLE 2 Accessibility Objectives Translated into Indicators that do not Reflect Accessibility

\begin{tabular}{lll}
$\begin{array}{l}\text { Metropolitan } \\
\text { Area }\end{array}$ & Objective & Definition \\
\hline Baltimore & Accessibility - Transit & Average Weekday Ridership \\
\cline { 2 - 3 } & Accessibility - Pedestrian / Bicycle & $\begin{array}{l}\text { Percentage of urban area directional roadway } \\
\text { miles that have sidewalks } \\
\text { Bicycle/walk-to-work mode share }\end{array}$ \\
\hline St-Paul & Access to Destinations & $\begin{array}{l}\text { Average annual hours of delay per capita } \\
\text { Transit ridership }\end{array}$ \\
\hline
\end{tabular}




\begin{tabular}{|c|c|c|}
\hline & & $\begin{array}{l}\text { Number of miles of managed lanes } \\
\text { Number of miles of bus-only shoulder lanes }\end{array}$ \\
\hline \multirow[t]{2}{*}{$\begin{array}{l}\text { Bay Area } \\
\text { (San Francisco) }\end{array}$} & Equitable access & $\begin{array}{l}\text { Decrease by } 10 \text { percentage points (to } 56 \text { percent } \\
\text { from } 66 \text { percent) the share of low-income and } \\
\text { lower-middle income residents' household } \\
\text { income consumed by transportation and housing }\end{array}$ \\
\hline & Access to Jobs & Average travel time in minutes for commute trips \\
\hline San Diego & Job Access & $\begin{array}{l}\text { The percentage of work trips lasting up to } 30 \\
\text { minutes during peak periods by driving alone, } \\
\text { riding in a carpool, and taking public transit }\end{array}$ \\
\hline Los Angeles & $\begin{array}{l}\text { Performance measures of } \\
\text { accessibility and mobility outcome }\end{array}$ & $\begin{array}{l}\text { Person delay per capita } \\
\text { Person delay by facility type } \\
\text { Truck delay by facility type } \\
\text { Travel time distribution for transit, SOV and } \\
\text { HOV modes for work and non-work trips } \\
\text { Work trips completed within } 45 \text { minutes }\end{array}$ \\
\hline
\end{tabular}

In conclusion, taken together, the results reveal that there still is a strong focus on mobility, although accessibility is included in most plans. This is consistent with previous studies in the UK and the US (Handy, 2005; Proffitt et al., 2015). Furthermore, accessibility objectives are seldom translated into accessibility indicators. This suggest that planners and/or decision-makers do understand the relevance of the concept of accessibility for improving quality of life and meeting the needs of the population, but that mobility approaches are still strongly rooted in the decisionmaking and analysis processes. This can be attributed to various reasons, such as lack of tools, lack of knowledge or lack of resources. Investigating these factors further however falls outside the scope of this research.

\section{RESULTS - IDENTIFYING BEST PRACTICES}

We have seen in the previous section that while many plans mention accessibility, few of them comprehensively address the ease of reaching destinations. In this section, we focus on those plans that do use accessibility indicators reflecting access to destinations, in order to identify the best practices and provide policy recommendations. Figure 1 presents the different types of accessibility analyses conducted in the various plans, and the types accessibility metrics used. 

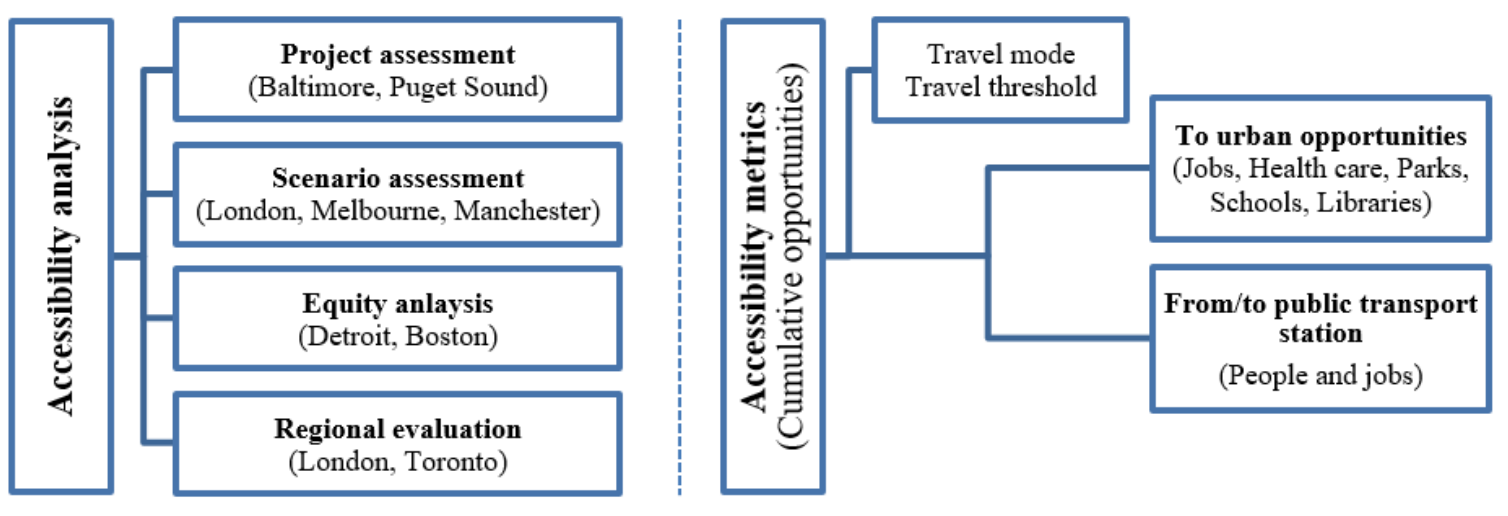

FIGURE 1 Use of Accessibility Indicators and Type of Accessibility Metrics in Regional Land Use and Transportation Plans

\section{Accessibility Analysis}

\section{Project and Scenario Assessment}

The most comprehensive accessibility analyses presented in the plans are generally related to project and scenario assessments (Figure 1). In such analysis, accessibility indicators are used to compare the benefits provided by different potential transportation investments and to inform decision-making.

One of the most systematic and transparent way to inform decision-making is by including accessibility indicators into multi-criteria analyses, as done by the Baltimore Regional Transportation Board, the Puget Sound Regional Council, Transport for London and the Greater Manchester Combined Authority. For example, in Baltimore, a multi-criteria analysis was conducted to compare the projects submitted by local jurisdictions and to select the ones to be included in the Regional Transportation Plan (Maximize 2040). Similarly, the Puget Sound Regional Council included accessibility in their multi-criteria analysis used to conduct a prioritization of the projects. With respect to scenario assessments, Transport for London used a multi-criteria analysis including accessibility indicators to assess the effectiveness of various modelling scenarios.

The accessibility indicators included in the multi-criteria analyses range from broad questions to specific quantified metrics, which influence the flexibility of the analysis. For example, Transport for London defines clear specific accessibility metrics, for example the change in the number of jobs accessible by public transport within 45 minutes travel time (see Table 1). These access to jobs metrics are relatively easy to generate and to interpret. Accordingly, they 
foster the inclusion of accessibility indicators that adequately reflect the ease of reaching destinations. Furthermore, given their specific nature, they are easy to communicate as exemplified in the plan: "Implementing the schemes will increase the employment catchment area of central London (the number of people within 45 minutes of central London employment) by almost 25 per cent." (p.74). In contrast, accessibility criteria in the Greater Manchester plan are defined with broad questions such as "Will the LTP help improve accessibility through integrated spatial planning?" and "Will the LTP improve access to jobs, particularly for people who suffer income or employment deprivation?" (see Table 1). These questions provide greater flexibility in the assessment of the plan, which can be beneficial as quantified metrics do not always reflect the benefits provided by improvements in accessibility (Curl et al., 2011). However, as emphasized by Halden (2011), it can also lead to the use and misuse of the concept of accessibility. An intermediate way of defining accessibility indicators is by attributing scores (from 1 to 3 for example) based on specific guidelines as done by the Baltimore Regional Transportation Board and the Puget Sound Regional Council. For example, in the Puget Sound multi-criteria analysis, a project receives 3 points if it supports access to institutions identified as economic foundations and another 2 points if it serves an area with an employment density above 15 jobs per acre. This approach has the advantage of defining clear weights associated with accessibility criteria, thus providing greater transparency. In the previous examples, the weights are not defined and accordingly do not indicate the relative influence of the accessibility aspects in the multi-criteria analysis. Overall, quantified metrics provide more specific guidelines that directly reflect the ease of reaching destinations. However, they provide lower flexibility and might not adequately reflect the outcomes of the different investments. Nevertheless, no matter the choice of indicators, including accessibility indicators in multi-criteria analysis provides a systematic alternative to mobility-focused decision-making. Furthermore, as highlighted by Halden (2011), the use of accessibility indicators "offers the potential for a new dimension in problem solving" (p.18).

Another important aspect of multi-criteria analysis is the clear distinction between mobility and accessibility indicators. In the Baltimore plan, the multi-criteria analysis includes the following goals: safety, accessibility, mobility, environmental conservation, security and economic prosperity. Interestingly, accessibility and mobility are included as two distinct goals with different criteria and methodologies, whereas in many plans accessibility and mobility are 
used interchangeably. This distinction ensures that distinct mobility and accessibility indicators are used for the respective objectives.

Other metropolitan areas have developed accessibility indicators to evaluate projects or progress toward accessibility objectives (Metropolitan Council - St-Paul, Southwestern Pennsylvania Commission, Southeast Michigan Council of Governments). These metropolitan areas set accessibility-based performance measures as guidelines for future project assessments. However, unlike the multi-criteria analyses presented above, these metropolitan areas have not themselves conducted an accessibility-based assessment of the projects. While define accessibility guidelines is a first step to foster the inclusion of accessibility-related performance indicators, directly including accessibility in the decision-making process of the plan sets a strong example and ensures that accessibility is directly taken into account. Overall, clear multi-criteria analysis, using clearly defined indicators, provide greater transparency and typically foster the inclusion of accessibility aspect in the decision-making process.

\section{Equity Analysis}

Equity analysis based on accessibility indicators are conducted by many metropolitan areas, especially in the US due to federal requirements. They generally assess the level of accessibility of specific vulnerable groups relatively the general population, using detailed accessibility metrics. However, in most cases the use of the generated accessibility metrics is limited to the environmental justice assessment, although accessibility is also stated as a main planning factor by the federal government. Accessibility is mainly perceived as an equity indicator, while it has the potential to address multiple aspects of a land use and transportation system. The marginal use of accessibility indicators for a general assessment of transportation investments might be explained by the lack of clarity of the federal planning factor, which requires to "increase the accessibility and mobility of people and for freight".

\section{Regional Evaluation}

Accessibility-based regional evaluation, which can be found in some of the plans, often provides greater transparency and efficient communication tools. Accessibility is discussed in terms of service coverage and/or service gaps, and in terms of regional benefits provided by the potential projects. For example, the NSW Government's Sydney Long Term Transport Master Plan identifies spatial transport gaps by mapping access to jobs by public transport and by car. The 
maps are used to discuss the regions in needs of improvement in terms of accessibility, and are the result of an extensive accessibility analysis. Similarly, the Paris transportation plan provides maps of access to jobs by transit and by car. Accessibility maps and metrics are useful tools to provide an overview of the land use and transportation network and they illustrate an underlying accessibility analysis. However, in the cases presented above, it appears unclear how accessibility metrics were used in the decision-making processes.

\section{Accessibility Metrics}

In terms of accessibility metrics, very similar metrics are used across the plans. Accessibility metrics are typically location-based and focus on the transport and land use components of accessibility. In all cases, measures are based on cumulative opportunities, using a travel time or distance threshold, mainly for public transport and driving (Figure 1, right). Cumulativeopportunity measures are easy to communicate and interpret, and thus better suited for planning documents (Geurs \& van Wee, 2004). Although they are not as theoretically sound as gravitybased measures, they are highly correlated with such measures (El-Geneidy \& Levinson, 2006) and are appropriate to measure accessibility at a regional level (Boisjoly \& El-Geneidy, 2016).

As illustrated in Figure 1, the measures can be divided in two categories: access to destinations, and access to or from public transport station. Access to public transport is the most common measure used in the plans. This measure is generally presented as the percentage of people or jobs that are within 0.5 mile of a public transport station. This is a measure of service coverage and is generally used by public transport authorities as a performance (see Southeast Michigan Council of Governments - Detroit Table 1). While the access to public transport dominates the plans, it does not directly addresses the ease of reaching urban opportunities. The second type of metrics (access to urban opportunities) directly measures the ease of reaching various destinations, generally jobs, using a specific mode. This measure is however more complex to generate, as the locations of the destinations is needed. Nevertheless, access to destinations, namely jobs, is not uncommon in the plans that we have assessed, especially with respect to social equity. Access to jobs provides an adequate indicator of regional accessibility, as many people commute across the region for work. Access to jobs can also be a reflection of the level of services available around a certain location, as the delivery of services often equates a certain number of employees. Other types of destinations include libraries, schools, grocery stores, hospitals, public 
parks, educational services as exemplified by the Atlanta Regional Commission. Many of these destinations reflect local accessibility and are thus often associated with cycling and walking. With respect to the individual components, many areas segment the accessibility analysis by socioeconomic groups. However, only few of them (Atlanta Regional Commission, Boston Region Metropolitan Planning Organization) do address destination segmentation. This is an important improvement as the accessibility to all jobs may not represent the opportunities that are available to different groups of populations.

In terms of modes and thresholds (Figure 1), accessibility to jobs is generally generated for transit or automobile, using travel time thresholds varying from 30 minutes to 60 minutes. Based on the existing literature, accessibility measures based on travel time thresholds adequately reflect accessibility, as they are highly correlated with mode choice (Alexandre Legrain et al., 2015; Andrew Owen \& Levinson, 2015). Measures of generalized costs (including the costs and time of travel) have been developed in the literature (Bocarejo \& Oviedo, 2012; El-Geneidy et al., 2016). These measures better reflect the total costs of travel as they include both financial and time burdens. They are however very challenging to generate due to complex fare structures and availability of data. Yet, excluding the financial costs of travel results in an overestimation of accessibility (El-Geneidy et al., 2016), especially for low-income individuals. In this regard, accessibility based on financial and time costs is closer to reality and can also provide an insight on fare structures and trip affordability. From a planning perspective, travel time measures of accessibility adequately represent accessibility patterns with respect to the transportation networks and locations of activities, but do not address the financial constraints that vulnerable individuals may face.

In terms of mode, most transport plans concentrate on including accessibility by transit and car, while few plans address access to destinations by cycling and walking. The most common metrics for cycling and walking are measures of local accessibility (to grocery stores, schools, parks or public transport station for example), as done by the Atlanta Regional Commission. Access to jobs by cycling or walking is included in the North Central Texas Council of Governments plan. With respect to local accessibility walking and cycling distance thresholds are used instead of travel time thresholds ( 0.5 miles for walking). These appear to be appropriate measures of accessibility, as time is generally proportional to the distance travelled by bicycle or 
foot. With public transport and driving, the travel distance is not always representative of the travel time, due to different speed limits, levels of congestion, and public transport route time efficiency.

Overall, the cumulative-opportunities accessibility metrics are generated for access to transport, and to a lesser extent, for access to destinations, mainly jobs. Ideally, plans would integrate both types of metrics. Access to transport provides a good indication of transport coverage, whereas access to destinations captures the performance of the land use and transportation systems, which better reflect the social and economic benefits (Banister, 2008; Koenig, 1980; Wachs \& Kumagai, 1973).

Furthermore, although this study focused on the physical component of accessibility, the results suggest that other dimensions of accessibility might currently be neglected in metropolitan transportation plans. For example, affordability, transfer and multimodal connectivity, as well as travel information did not come up as main aspects of accessibility objectives. These are however key component of accessibility and should thus be addressed in further research.

\section{Accessibility Beyond Metropolitan Transportation Plans}

Although this study was limited to metropolitan transportation plans, it is important to note that several academic, governmental and private institutions have come further in the generation of accessibility-based metrics planning tools than what is displayed in the plans.

To start with, multiple private, governmental and non-governmental institutions, namely in the US, have generated access-to-destinations metrics by various modes and have made them openly available on the web, generally through accessibility maps (Accessibility Observatory, 2016; City of Portland, 2016; New York Regional Plan Association, 2016; Travel Behavior \& Urban Systems Research Group at University of Illinois at Chicago, 2016; US Environmental Protection Agency, 2016; Walk Score, 2016). As observed in the plans, cumulative-opportunities access-to-jobs metrics, namely by transit, car and walking, are commonly used, with a variety of time thresholds. Interestingly, a few institutions provide access-to-jobs metrics by sector (Walk Score, 2016), level of education (New York Regional Plan Association, 2016; Travel Behavior \& Urban Systems Research Group at University of Illinois at Chicago, 2016) or other characteristics such as income level and ethnicity of workers (Travel Behavior \& Urban Systems Research Group at University of Illinois at Chicago, 2016). In addition to jobs, destinations such as parks, municipal services, hospitals and grocery stores are sometimes included (City of Portland, 2016; Travel Behavior \& Urban Systems Research Group at University of Illinois at Chicago, 2016). While the 
accessibility maps and metrics are openly available, the dataset, which can directly be used to conduct accessibility analysis, is typically not. The US Environmental Protection Agency (2016) however provides the Access to Jobs and Workers Via Transit Tool, from which data can be downloaded. In addition to the data readily available, multiple institutions provide accessibility instruments or software that can be used by planning agencies or municipalities to generate accessibility metrics and analysis. For example, the COST initiative Accessibility Instruments For Planning Practice In Europe provides an overview of several such instruments (Brommellstroet, Silva, \& Bertolini, 2014; COST, 2016).

This section has highlighted the variety of tools potentially available to planners or municipalities to collect or generate accessibility data. The low penetration of accessibility metrics in metropolitan transportation plans calls for further research examining the dissemination and use of existing accessibility tools. Such efforts have been initiated by researchers aiming to assess the usability of accessibility metrics and instruments in practice (Boisjoly \& El-Geneidy, 2016; Brommellstroet et al., 2014). Remaining issues include the barriers and opportunities associated with the dissemination of tools and their uptake by planners.

In addition to the tools discussed above, detailed metropolitan accessibility analyses have been conducted by academic research groups. For example, the Center for Transportation Studies (CTS) published an extensive analysis of access to destinations in the Minneapolis-St. Paul metropolitan region (CTS, 2010). Yet, there is no indication that this specific analysis was included in the Metropolitan Council - St-Paul 2040 Transport Policy Plan. The Transportation Research at McGill group also conducted an accessibility analysis for the region of Toronto (Transportation at Research McGill (TRAM), 2014). The analysis was specifically prepared for Metrolinx, Toronto's metropolitan transport authority, which has included some of the metrics in its Discussion Paper for the next Regional Transportation (Metrolinx, 2016). In this regard, further research should examine the collaboration processes between academic institutions and research groups, as it provides a fertile area for supporting the implementation of accessibility-based approaches.

\section{DISCUSSION AND CONCLUSION}

The assessment of multiple plans reveals that there is a trend toward the integration of accessibility objectives, rather than merely mobility. Most plans emphasize the need to improve accessibility, or access to destinations, which indicates a shift from the traditional transportation planning 
approaches (Banister, 2008). However, the transition towards accessibility-based planning is far from complete. Practically speaking, few plans have accessibility-based indicators that guide their decision-making processes. There is indeed often a discrepancy between the accessibility objectives that are stated in the plans, and the performance indicators that are actually used to make decisions.

Although the concept of accessibility dates back to the $1950 \mathrm{~s}$, it is a relatively recent planning tool. Mobility approaches, which have dominated transportation planning since the widespread use of the car in the 1950s, are still strongly rooted in practice. More efforts are needed to effectively implement accessibility-based approaches. In this regard, this section discusses the best practices to help practitioners and cities wishing to integrate effective accessibility planning approaches. The best practices are identified in light of the assessment given and are presented in TABLE 3.

TABLE 3 Best Practices for a Greater Inclusion of Accessibility Planning and Metrics

\begin{tabular}{|c|c|c|}
\hline Recommendation & Description & Key examples \\
\hline Accessibility goals and objectives & $\begin{array}{l}\text { Clearly defined goals and objectives are } \\
\text { included in the plan. } \\
\text { The plan is structured around the goals and } \\
\text { objectives. }\end{array}$ & London \\
\hline $\begin{array}{l}\text { Distinction between accessibility } \\
\text { and mobility }\end{array}$ & $\begin{array}{l}\text { Distinct accessibility and mobility objectives } \\
\text { and indicators are defined. }\end{array}$ & Baltimore \\
\hline $\begin{array}{l}\text { Multi-criteria analysis including } \\
\text { accessibility indicators }\end{array}$ & $\begin{array}{l}\text { Accessibility indicators are systematically } \\
\text { included in the performance analyses. } \\
\text { Accessibility metrics are used to assess the } \\
\text { general performance of the land use and } \\
\text { transportation system, in addition to social } \\
\text { equity. }\end{array}$ & $\begin{array}{l}\text { London, Baltimore, Puget } \\
\text { Sound (Seattle), } \\
\text { Manchester, Melbourne }\end{array}$ \\
\hline Access to destinations metrics & $\begin{array}{l}\text { The accessibility indicators are based on } \\
\text { access to destinations (e.g.: jobs), rather than } \\
\text { to transport amenities (e.g.: public transport } \\
\text { stop) }\end{array}$ & Boston \\
\hline Multiple modes & $\begin{array}{l}\text { Accessibility is measured for various modes } \\
\text { of transport }\end{array}$ & $\begin{array}{l}\text { North Central Texas, } \\
\text { Atlanta }\end{array}$ \\
\hline Visualization tools & Accessibility maps are included in the plan. & London, Sydney \\
\hline
\end{tabular}

The goals and objectives are key elements of a transportation plan, as they guide the specific planning targets (Handy, 2008). Although not always translated into practice, planning 
goals can determine the main directions of a plan. This is especially the case when plans are clearly structured around the goals and objectives as demonstrated by Transport for London, rather than around projects or investments. Furthermore, to ensure that accessibility goals are translated into practice, it is key to have clearly defined goals reflecting the ease of reaching destinations. In contrast, broad accessibility goals can be interpreted in multiple ways that do not necessarily address access to destinations (Curl et al., 2011; Halden, 2011). For example, the US federal government defines eight planning factors that guide the development of the Transportation Plans by the MPOs, one of which is to "increase the accessibility and mobility of people and for freight" (U.S. Department of Transportation, 2014). As accessibility is not clearly defined, access to destinations is often not reflected in the plans. Accessibility goals should hence be clearly defined to encourage the establishment of accessibility-based performance indicators.

Another key element to ensure that accessibility goals are translated into accessibility indicators is to have distinct mobility and accessibility goals. As accessibility objectives are often translated into mobility indicators (see TABLE 2), the definition of two distinct objectives can prevent such practices as seen in the Baltimore plan. In its multi-criteria analysis, the Baltimore plan defines six distinct goals, one of which is accessibility and one of which is mobility. As a result, the indicators falling under the accessibility goal are specific to accessibility and reflect the ease of reaching destinations. Furthermore, a clear distinction should be made between access to mobility, access to destinations (Levine et al., 2012) and universal accessibility. This can be encouraged by the clear definition of objectives, as highlighted in the first recommendation.

In this regard, the use of access to destinations metrics such as cumulative-opportunity metrics provide indicators that typically reflect the ease of reaching destinations and is thus encouraged. More specifically, the use of cumulative-opportunities measure of accessibility to jobs by public transport and car is suggested. These measures provide adequate indicators of the regional patterns of accessibility, and are easy to generate, to interpret, and to communicate (Boisjoly \& El-Geneidy, 2016; Geurs \& van Wee, 2004). More detailed analysis can include other types of destinations, or segmentation by job types, to address specific social issues, all depending on the context of analysis. Temporal fluctuations in accessibility can also be addressed to improve the quality of the accessibility analysis. Furthermore, while most plans focus on car accessibility, and to a lesser extent on accessibility by transit, all modes should be included in the accessibility 
objectives and indicators. Increasing accessibility by transit, cycling and walking can contribute to achieving broader environmental, economic and social goals.

In order to further foster accessibility-based planning approaches, accessibility indicators should systematically be included in multi-criteria analyses as in the case of London, Baltimore and Puget Sound. Although this does not ensure that decisions will be made based on the accessibility analysis, it offers an alternative to mobility-based decisions and potentially provide greater transparency in the decision-making process (Halden, 2011). Furthermore, national and regional authorities can require local authorities to address accessibility in their project analysis. One especially effective way of doing so is by including accessibility criteria in the selection process of projects, as done by Baltimore. Another approach is by defining guiding factors on which projects should be analyzed, as done by the St-Paul Regional Council. This encourages the integration of accessibility-based indicators, but might not be as efficient as a systematic multicriteria analyses conducted to select projects. It is also important to note that accessibility indicators should be used as general performance indicators and should not be limited to social equity analyses. Many plans from American metropolitan areas generate accessibility measures to address the environmental justice federal requirement. Yet, accessibility allows tackling multiple objectives, including environmental and economic benefits (Handy, 2002; Koenig, 1980), and should hence also be used to assess the overall benefits of potential investments.

Another good practice to address accessibility in transport plan is the use of visualization tools such as maps. Accessibility maps provide a clear way to communicate gaps and benefits of a transportation and land use network, and thus helps decision-makers, planners and the general population to better grasp the impacts of transportation investments. A key example is the London plan which provides before and after maps of accessibility to highlight the impacts of the transportation plan.

This study has explored the current use of accessibility in metropolitan transportation plans and provided several recommendations for promoting accessibility-based approaches. Yet, important aspects of accessibility fall outside the scope of this research and could be further explored in future studies. In order to understand to what extent decisions are made based on accessibility issues, it would be relevant to examine decision-making processes in their ensemble. Furthermore, an important aspect is to evaluate the actual social and economic impacts of 
accessibility improvements resulting from plans. Lastly, an evaluation of the implementation of the projects presented in the plans would be essential. 


\section{REFERENCES}

Accessibility Observatory. (2016). Access across America. Retrieved September 12th, 2016, from http://ao.umn.edu/

Atlanta Regional Commission. (2016). The Atlanta region's plan: Transportation.

Baltimore Regional Transportation Board. (2016). Maximize 2040: A performance-based transportation plan for a greater Baltimore region.

Banister, D. (2008). The sustainable mobility paradigm. Transport Policy, 15(2), 73-80.

Ben-Akiva, M., \& Lerman, S. (1979). Disaggregate travel and mobility choice models and measures of accessibility. In D. Hensher \& P. Stopher (Eds.), Behavioural travel modelling (pp. 654-679). London: Croom-Helm.

Bocarejo, J., \& Oviedo, D. (2012). Transport accessibility and social inequities: A tool for identification of mobility needs and evaluation of transport investments. Journal of Transport Geography, 24, 142-154.

Boisjoly, G., \& El-Geneidy, A. (2016). Daily fluctuations in transit and job availability: A comparative assessment of time-sensitive accessibility measures. Journal of Transport Geography, 52, 73-81.

Boston Region Metropolitan Planning Organization. (2015). Long range transportation plan 2040.

Brommellstroet, M., Silva, C., \& Bertolini, L. (2014). Accessing usability of accessibility instruments. Amsterdam: COST.

Bruxelles Mobilité. (2011). Plan de mobilité régionale (Iris II).

City of Melbourne. (2012). Transport strategy 2012 - Planning for growth.

City of Portland. (2016). 20-Minute Neighborhoods. Retrieved September 15th, 2016, from http://tinyurl.com/n7hg87k

Conseil régional d'île-de-France. (2014). Plan de déplacements urbains île-de-France.

COST. (2016). Accessibility Instruments for Planning Practice. Retrieved September 15th, 2016, from http://www.accessibilityplanning.eu/

CTS. (2010). Measuring what matters: Access to destinations, the second research summary from the access to destinations study Center for Transportation Studies, University of Minnesota.

Curl, A., Nelson, J., \& Anable, J. (2011). Does Accessibility Planning address what matters? A review of current practice and practitioner perspectives. Research in Transportation Business \& Management, 2, 3-11.

Delaware Valley Regional Planning Commission. (2013). Connections 2040.

Dodson, J., Gleeson, B., Evans, R., \& Sipe, N. (2007). Investigating the social dimensions of transport disadvantage II: From concepts to methods through an empirical case study. Urban Policy and Research, 25(1), 63-89. doi: 10.1080/08111140701225511

El-Geneidy, A., \& Levinson, D. (2006). Access to destinations: Development of accessibility measures. StPaul, Minnesota, U.S.: Departement of civil engineering, University of Minnesota.

El-Geneidy, A., Levinson, D., Diab, E., Boisjoly, G., Verbich, D., \& Loong, C. (2016). The cost of equity: Assessing transit accessibility and social disparity using total travel cost. Transportation Research Part A, 302-316.

Fan, Y., Guthrie, A., \& Levinson, D. (2012). Impact of light rail implementation on labor market accessibility: A transportation equity perspective. Journal of Transport and Land Use, 5(3).

Geurs, K., Krizek, K., \& Reggiani, A. (2012). Accessibility analysis and transport planning: An introduction. In K. Geurs, K. Krizek \& A. Reggiani (Eds.), Accessibility Analysis and Transport Planning: Challenges for Europe and North America (pp. 1-12). Northampton: Edward Elgar Publishing Limited.

Geurs, K., \& van Wee, B. (2004). Accessibility evaluation of land-use and transport strategies: Review and research directions. Journal of Transport Geography, 12, 127-140.

Greater Manchester Combined Authority. (2011). Local Transport Plan 3. 
Halden, D. (2011). The use and abuse of accessibility measures in UK passenger transport planning. Research in Transportation Business \& Management, 2, 12-19.

Handy, S. (1994). Regional versus local accessibility: Implications for non-work travel. Transportation Research Record(1400), 58-66.

Handy, S. (2002). Accessibility- vs. mobility-enhancing strategies for addressing automobile dependence in the U.S. In Institute of Transportation Studies (Ed.), Recent Work. Davis, US: University of California.

Handy, S. (2005). Planning for accessibility: In theory and in practice. In D. Levinson \& K. Krizek (Eds.), Access to destinations (pp. 131-147). Oxford, UK: Elsevier.

Handy, S. (2008). Regional transportation planning in the US: An examination of changes in technical aspects of the planning process in response to changing goals. Transport Policy, 15(2), 113-126.

Handy, S., \& Niemeier, D. (1997). Measuring accessibility: An exploration of issues and alternatives. Environment and Planning A, 29, 1175-1194.

Hansen, W. (1959). How accessibility shapes land use. Journal of the American Institute of Planners, 25(2), 73-76.

Houston-Galveston Area Council. (2016). Bridging Our Communities.

Hsieh, H., \& Shannon, S. (2005). Three approaches to qualitative content analysis. Qualitative health research, 15(9), 1277-1288.

Koenig, J. (1980). Indicators of urban accessibility: Theory and application. Transportation, 9(2), 145-172.

Legrain, A., Buliung, R., \& El-Geneidy, A. (2015). Who, what, when and where: Revisiting the influences of transit mode share. Transportation Research Record.

Legrain, A., Buliung, R., \& El-Geneidy, A. (2016). Travelling fair: Targeting equitable transit by understanding job location, sectorial concentration, and transit use among low-wage workers. Journal of Transport Geography, 53, 1-11.

Levine, J., Grengs, J., Shen, Q., \& Shen, Q. (2012). Does accessibility require density or speed? A comparison of fast versus close in getting where you want to go in US metropolitan regions. Journal of the American Planning Association, 78(2), 157-172.

Levinson, D., Gillen, D. (2005). The machine for access. In D. Levinson \& K. Krizek (Eds.), Access to Destinations. Oxford,UK: Elsevier.

Lille Métropole Communauté Urbaine. (2011). Plan de déplacements urbains 2010-2020.

Litman, T. (2013). The new transportation planning paradigm. Institute of Transportation Engineers (ITE) Journal, 83(6), 20.

Lucas, K. (2012). Transport and social exclusion: Where are we now? Transport Policy, 20, 107-115.

Manaugh, K., Badami, M., \& El-Geneidy, A. (2015). Integrating social equity into urban transportation planning: A critical evaluation of equity objectives and measures in transportation plans in North America. Transport Policy, 37, 167-176.

Maricopa Association of Governments. (2006). Regional Transportation Plan.

Mayor's Council on Regional Transportation. (2014). Vancouver transportation investment.

Mayring, P. (2014). Qualitative content analysis: Theoretical foundation, basic procedures and software solution: GESIS - Leibniz Institute for the Social Sciences.

Metrolinx. (2008). The Big Move.

Metrolinx. (2016). Discussion paper for the next regional transportation plan. Toronto: Metrolinx.

Metropolitan Council - St-Paul. (2015). 2040 Transportation Policy Plan.

Metropolitan Transportation Commission. (2013). Bay Area Plan 2035.

Miller, H. J. (2005). Place-based versus people-based accessibility. In D. M. L. a. K. J. Krizek (Ed.), Access to destinations (pp. 63-89). Oxford: Elsevier.

Morris, J., Dumble, P., \& Wigan, M. (1979). Accessibility indicators for transport planning. Transportation Research Part A: General, 13(2), 91-109. 
National Capital Region Transportation Planning Board. (2015). Washington Transportation Plan 2035. New York Metropolitan Transportation Council. (2013). Plan 2040.

New York Regional Plan Association. (2016). Access to jobs. Retrieved September 10th, 2016, from http://fragile-success.rpa.org/maps/jobs.html

North Central Texas Council of Governments. (2016). Mobility 2040.

North Jersey Transportation Planning Authority. (2013). Plan 2040.

NSW Government. (2012). NSW Long Term Transport Master Plan.

Owen, A., \& Levinson, D. (2014) Access across America: Transit 2014 methodology. Minneapolis, MN: University of Minnesota.

Owen, A., \& Levinson, D. M. (2015). Modeling the commute mode share of transit using continuous accessibility to jobs. Transportation Research Part A: Policy and Practice, 74, 110-122. doi: 10.1016/j.tra.2015.02.002

Paez, A., Mercado, R. G., Farber, S., Morency, C., \& Roorda, M. (2010). Accessibility to health care facilities in Montreal Island: an application of relative accessibility indicators from the perspective of senior and non-senior residents. International Journal of Health Geographics, 9(52), 1-15.

Paez, A., Scott, D. M., \& Morency, C. (2012). Measuring accessibility: Positive and normative implementations of various accessibility indicators. Journal of Transport Geography, 25, 141 153.

Preston, J., \& Rajé, F. (2007). Accessibility, mobility and transport-related social exclusion. Journal of Transport Geography, 15, 151-160.

Proffitt, D., Bartholomew, K., Ewing, R., \& Miller, H. (2015). Accessibility planning in american metropolitan areas: Are we there yet? Paper presented at the Transportation Research Board 94th Annual meeting, Washington, D.C.

Puget Sound Regional Council. (2014). Transportation 2040 Plan Update.

San Diego Association of Governments. (2011). 2050 Regional Transportation Plan.

Senate Department for Urban Development and the Environment of the State of Berlin. (2014). Urban Transportation Development Plan 2025.

Singapore Land Transport Authority (LTA). (2013). Land Transport Master Plan 2013. Singapore: Singapore LTA.

Southeast Michigan Council of Governments. (2013). Regional Transportation Plan 2040.

Southern California Association of Governments. (2016). Regional Transportation Plan 2040.

Southwestern Pennsylvania Commission. (2014). Report on Environmental Justice.

Stockholm, C. o. (2010). Urban Mobility Strategy.

Straatemeier, T. (2008). How to plan for regional accessibility? Transport Policy, 15(2), 127-137.

The Chicago Metropolitan Agency for Planning. (2014). Go To 2040 Plan Update Summary.

Transport for London. (2006). Tranpsort 2025: Transport Vision for a Growing World City.

Transportation at Research McGill (TRAM). (2014). Non-stop equity: Assessing daily intersections between transit accessibility and social disparity across the Greater Toronto and HamiltonArea (GTHA). Toronto, Canada: Metrolinx.

Travel Behavior \& Urban Systems Research Group at University of Illinois at Chicago. (2016). Metropolitan Chicago Accessibility Explorer. Retrieved September 16th, 2016, from http://urbanaccessibility.com/

U.S. Department of Transportation. (2014). Model long-range transportation plans: A guide for incorporating performance-based planning.

US Environmental Protection Agency. (2016). Smart Location Mapping. Retrieved September 15th, 2016, from https://www.epa.gov/smartgrowth/smart-location-mapping\#Trans 45 
Vickerman, R. (1974). Accessibility, attraction, and potential: A review of some concepts and their use in determining mobility. Environment and Planning A, 6, 675-691.

Ville de Montréal. (2008). Montreal Transportation Plan.

Wachs, M., \& Kumagai, T. (1973). Physical accessibility as a social indicator. Socio-Economic Planning Sciences, 7(5), 437-456.

Walk Score. (2016). Opportunity Score. Retrieved September 16th, 2016, from https://labs.redfin.com/opportunity-score

West Midlands CEPOG. (2010). Local Transport Plan 3 - Making the Connections. 